\title{
SIMBOL KEAGAMAAN DALAM ISLAM DAN IDEOLOGI
}

\section{TELEVISI}

\author{
Siti Solikhati \\ Jurusan KPI Fakultas Dakwah dan Komunikasi UIN Walisongo \\ Sholy_zain@yahoo.com
}

\begin{abstract}
$B$ asically human lives are built based on fragmented symbols which form the real picture of the whole world. People expressed every side of their lives (including religious live) using certain symbols which are socially accepted. The discussion on religious symbols has always leads to two means, namely socio-cultural symbols which associate religious doctrines with the local culture, and normative symbols which are supposed to be permanent symbols. The discussion on this paper focused on the nuance of the meaning of religious symbols which have shifted more on cultural meaning rather than the normative ones, as can be seen on television religious programs.

Accordingly, television has its own way of expressing things based on their own management policy, in which usually they use market needs as the main reason. To fulfill the market needs however, the medium need to wrap religious message up using certain symbols to fit their audience needs. According to Fiske (1987) it will be easier to have a look the ideology used by television by take a close look at how it uses certain symbols.
\end{abstract}

Keywords: Symbols, Ideology, Local Culture

\begin{abstract}
ABSTRAK
$\mathrm{K}$ ehidupan manusia ini terdiri dari serpihan-serpihan simbol yang kemudian terpola dan membentuk kesatuan dunia secara utuh. Manusia mengekspresikan diri, termasuk di dalamnya mengekspresikan aspek kehidupan beragama menggunakan simbol yang telah disepakati secara sosial. Wacana simbol dalam kehidupan beragama mengandung makna multi dimensi, yaitu dimensi sosiokultural yang bisa berubah sesuai dengan konteks, serta dimensi normative yang bersifat permanen dan mutlak. Konteks wacana symbol keagamaan dalam paper ini difokuskan pada pergeseran makna symbol keagamaan yang bersifat normative lebih banyak berfungsi sebagai symbol kultural sebagaimana diperlihatkan pada tayangan-tayangan keagamaan di televisi.

Televisi memiliki cara tersendiri untuk mengemas informasi tertentu berdasarkan konsep kebijakan internal dan menggunakan argument segmen audience. Untuk memenuhi target audience, maka televisi perlu mengemas pesan keagamaan menggunakan symbol yang telah disesuaikan dengan kebutuhan audience. Menurut Fiske (1987) dengan melihat bagaimana televisi menggunakan symbol-simbol tertentu, maka akan mudah untuk melihat ideologi yang terkandung di dalamnya.
\end{abstract}

Kata Kunci : Simbol, Ideologi, kultur lokal

Islamic Comunication Journal Volume 02, Nomor 02, Juli-Desember 2017 


\section{PENDAHULUAN}

Islam merupakan ajaran agama yang disampaikan kepada para penganutnya dengan menggunakan simbol-simbol yang bersifat permanen. Berkenaan dengan proses penyebarannya, secara normatif Islam bersifat elitis dalam arti bahwa secara kewenangan serta kompetensi untuk menyampaikan ajaran ini tidak dimiliki oleh semua orang, tetapi menjadi wilayah orang-orang yang dianggap memenuhi syarat dan kriteria tertentu. Meskipun demikian, secara pragmatis proses penyebaran ajaran Islam tidak selamanya berbanding lurus dengan bagaimana Islam diwacanakan secara normatif. Dalam praktiknya, penyebaran ajaran agama ini berjalan sesuai dengan perkembangan sosiokultural. Secara kultural, proses penyebaran ajaran Islam baik secara tatap muka langsung maupun melalui media, terjadi melalui beberapa tahapan interpretasi oleh para penyebar serta penerima ajaran. Ajaran agama disebarkan menggunakan simbolsimbol keagamaan yang telah disesuaikan melalui proses interpretasi oleh pembawa risalah, dan diterima dengan cara yang telah disesuaikan dengan pola interpretasi dari penerima risalah.

Salah satu media komunikasi modern yang banyak digunakan untuk menyebarkan ajaran ini adalah televisi. Ketika ajaran Islam disebarkan melalui media televisi, secara tidak langsung format siarannya menyesuaikan dengan karakter entertaining yang dimiliki media tersebut. Dalam hal ini terjadi interaksi antara simbol keagamaan yang bersifat sakral dengan simbol televisi yang bersifat kultural. Percampuran antara simbolsimbol keagamaan dan simbol kultural potensial menyebabkan semakin rumitnya mata rantai interpretasi terhadap ajaran agama.

Berkaitan dengan adanya peristiwa interpretasi yang menimbulkan multitafsir terhadap makna pesan keagamaan, potensi multitafsir semakin kelihatan karena adanya variasi dalam peristiwa representasi ajaran Islam ke dalam bentuk simbol-simbol keagamaan yang sudah disesuaikan dengan budaya media. Disamping itu, para penyebar ajaran Islam yang dijadikan rujukan oleh media televisi mempunyai pola tafsir yang berbeda-beda sehingga hal ini potensial untuk menambah semakin kompleksnya multi proses cara tafsir terhadap ajaran tersebut. Keaneka ragaman penggunaan simbol-simbol keagamaan dalam merepresentasikan ajaran Islam ini setidaknya bisa dilihat dalam tayangan keagamaan di televisi yang dikemas dalam bentuk hiburan, khususnya dalam bentuk program sinetron.

Secara umum, bentuk-bentuk representasi Islam dengan menggunakan simbol- 
simbol keagamaan dalam sinetron reliji bisa dilihat dari adanya proses simplifikasi dalam menjelaskan sebuah ajaran atau doktrin ajaran, misalnya dalam penggunaan atribut keagamaan, eksploitasi ayat-ayat suci, penggunaan dialog, dan penyederhanaan penyelesaian akhir dalam sebuah problem solving. Bentuk representasi Islam dengan menggunakan simbol-simbol keagamaan yang demikian ini pada tahapan tertentu bisa mengakibatkan penyederhanaan pemahaman penonton tentang ajaran keagamaan. Taylor dan Harris menjelaskan bahwa ciri televisi dalam menayangkan program fiksi biasanya mengedepankan meta-story serta melakukan ideological reduction yang bisa mengakibatkan terjadinya kebanalan atau pendangkalan makna (2008: 163). Penggunaan simbol-simbol keagamaan dalam sebuah tayangan program sinetron atau film tidak lepas dari konstruksi ide tentang obyek keagamaan yang direpresentasikan dalam bentuk tampilan yang mengedepankan efek easy consuming, sehingga ide pokok dari ajaran Islam lebih mudah diterima oleh penonton.

Selanjutnya, jika dilihat dari perspektif ideologi media, bergesernya makna akibat penggunaan simbol-simbol keagamaan dalam merepresentasikan ajaran agama nampaknya menjadi hal yang tak terhindarkan dalam bisnis media. Hal ini ditambah dengan kecenderungan orientasi bisnis dari para penyebar Islam yang terlibat dalam proses tersebut. Ideologi kapitalis yang dianut televisi serta penyebar ajaran Islam dalam mentransmisikan nilai-nilai agama ini memunculkan keprihatinan di kalangan umat Islam (Ibrahim: 2005).

\section{WACANA SIMBOL}

Secara terminologis, kata simbol sering menimbulkan pengertian yang berbeda-beda. Dalam Collin Cobuild, simbol didefinisikan sebagai: (1) "a shape or design that is used to represent something such as an idea”, (2) "something that seems to represent society or aspects of life, because it is very typical of it” (Collin Cobuild, 1987: 1482). Sedangkan dalam Dictionary of Sociology (Jary and Jary, 1991: 645), kata simbol didefinisikan sebagai: (1). "A sign, in which the connection between the meaning and the sign is conventional rather than natural", (2). "An indirect representation of an underlying meaning, syndrome, etc, as for example, in religious symbolism and ritual'. Karena hubungan antara makna dan tanda lebih bersifat konvensional sebagaimana disebutkan Jary and Jary, maka sebuah simbol tidak selamanya mengandung makna universal, tetapi pemaknaan terhadap simbol akan tergantung pada komunitas masyarakat dimana simbol tersebut digunakan. Menurut Berger (2010: 29), sebuah simbol bisa dianggap bersifat konvensional karena 
seringkali manusia menafsirkan simbolsimbol tersebut dan mengasosiasikan serta menerapkannya dalam budaya mereka sendiri.

Mengenai terminologi simbol, Morris menjelaskan bahwa simbol telah sering digunakan untuk memaknai segala sesuatu mulai dari tanda-tanda yang bersifat sangat sederhana hingga digunakan untuk menjelaskan gambaran yang lebih rumit dari sebuah cerita, bahkan simbol sering digunakan untuk mengungkapkan argumen yang bersifat filosofis (http://www.fiu.edu / morriss/, diakses 12 Juli 2014). Selanjutnya Morris menjelaskan “A symbol is any sign which also has an inherent connection to that greater thing or image to which it points", bahkan istilah simbol juga digunakan dalam desain grafis, mitos, dan kejadian-kejadian, hingga gambaran tentang manusia dan tempat. Dalam menjelaskan "symbols are more than just cultural artefacts: in their correct context, they still speak powerfully to us, simultaneously addressing our intellect, emotions, and spirit". Ini berarti bahwa simbol tidak bisa dimaknai secara tunggal dan universal, karena ia berkaitan dengan hal-hal lain yang lebih luas dari simbol itu sendiri.

Liliweri (2011: 4-6) menjelaskan bahwa dalam perkembangan komunikasi, manusia memiliki lima tahapan sejarah mengenai simbol yang secara garis besar bisa diklasifikasikan sebagai berikut:

1. Cave painting, adalah sejenis rock art yang merupakan simbol tertua di zaman Paleolitik. Lukisan yang diperkenalkan oleh Chauvet Cave pada tahun 30.000 SM ini digunakan oleh manusia untuk menginformasikan tentang keberadaan dirinya.

2. Petroglif, merupakan karya yang menyerupai lukisan pada batu-batu cadas yang diperkirakan ada pada tahun sekitar 20.000 - 10.000 SM. Lukisan yang juga dibuat pada kayu-kayuan ini digunakan sebagai pengingat yang diperkirakan dibuat oleh para pemburu di daerah Afrika atau Oceania.

3. Piktograf, yang dikenal sebagai proto-writing adalah simbol yang mewakili konsep atau obyek, aktifitas, tempat, dan peristiwa dalam bentuk ilustrasi. Piktograf digunakan dalam kebudayaan kuno pada sekitar tahun 9.000 SM.

4. Ideogram, dianggap sebagai sistem penulisan logografis yang telah lama dikenal di Mesir dan Cina. Ideogram berupa konsep yang sangat abstrak, tetapi bisa digunakan untuk menyampaikan ide-ide yang bersifat 
universal, misalnya dua tongkat dianggap menggambarkan kaki tetapi bisa mewakili konsep tentang berjalan.

5. Writing, yang ditemukan pertama kali pada tahun 400 SM dan dikembangkan berdasarkan kategori logografik, silabik, dan alphabetik. Variasi tulisan dari masing-masing wilayah bersifat unik dan berbeda satu dengan lainnya.

Dengan melihat penjelasan tentang simbol serta sejarah simbol, maka bisa diambil pemahaman bahwa kehidupan manusia tidak bisa lepas dari dunia simbol, dan bahwa seluruh aspek kehidupan manusia terdiri dari proses produksi dan konsumsi simbol. Konsep Cassirer tentang manusia sebagai makhluk simbolik atau animal symbolicum (dalam Verene, 1979) merupakan gagasan yang dijadikan rujukan penting. Dalam konteks tulisan ini penulis menggunakan kata "simbol" sebagai segala sesuatu yang berkaitan dengan produk yang dipertukarkan oleh manusia sebagai pesanpesan komunikasi --baik yang berupa gambar, lambang, ucapan, tulisan, sikap, dan perilaku-- yang merepresentasikan semua aspek kehidupan manusia. Definisi simbol yang digunakan dalam penelitian ini mengacu pada batasan terminologi simbol dari Turner (1982: 19), yaitu: “objects, activities, relationships, events, gestures, and spatial units" yang secara empirik telah digunakan untuk mengamati proses ritual komunitas masyarakat Ndembu yang dipenuhi dengan peristiwa-peristiwa simbolik

Dalam praktek kehidupan sosial, simbol yang berlaku pada sebuah komunitas bisa digunakan untuk membedakan jenis kegiatan manusia, misalnya apakah kegiatan tersebut dinilai sebagai hal yang natural atau supranatural, yang bersifat profan atau sakral. Menurut Beattie (1964: 202), semua simbol bisa dianggap sebagai jenis bahasa dimana orang menggunakannya untuk mengungkapkan tentang sesuatu, serta mengekspresikan perilaku simbolik yang dianggap memiliki bermacam-macam nilai sosial yang penting. Simbol juga digunakan sebagai alat ekspresi manusia yang menjelaskan bahwa dengan perilaku simbolik itu seseorang bisa dimaknai apakah dia 'sedang menginginkan sesuatu' atau sebaliknya bisa juga dia 'sedang mencegah dan menolak sesuatu'.

Selanjutnya Beattie (1964: 224-229) menjelaskan bahwa pemaknaan terhadap simbol bisa diklasifikasikan menjadi tiga, yaitu pemaknaan yang bersifat personal (personalized), pemaknaan yang bersifat kultural, dan pemaknaan yang bersifat universal. Klasifikasi personal dan kultural dalam pemaknaan ini didasarkan oleh 
perbedaan pengalaman, cara merasa, dan cara pandang terhadap simbol-simbol tertentu. Sedangkan klasifikasi universal didasarkan pada generalisasi karakter dasar manusia yang mempunyai kesamaan persepsi terhadap hal hal tertentu. Misalnya, ekspresi simbolik manusia yang berkaitan dengan hantu dan ruh halus bisa berbeda secara individual disebabkan oleh pengalaman spiritual yang berbeda dari masing masing individu. Sistem budaya yang dianut seseorang juga menyebabkan perbedaan dalam mengungkapkan perilaku spiritual secara simbolik.

Dalam praktek penggunaan simbol, pentingnya kegunaan simbol bagi manusia ditekankan oleh Cassirer, bahwa pada dasarnya manusia tidak memiliki kemampuan untuk memahami dunia ini dalam satu kesatuan yang utuh, melainkan manusia memahami dunia ini secara terpecah-pecah menjadi berbagai wilayah pemikiran dan wilayah kebudayaan. Untuk memahami keterpecahan wilayah ini maka Cassirer membuat asumsi bahwa manusia adalah animal symbolicum dimana mereka menandai segala bentuk kegiatan, benda, dan pemikiran mereka secara simbolik (dalam Verene, 1979: 12). Dengan demikian maka keseluruhan kehidupan manusia ini terdiri dari serpihan-serpihan simbol yang kemudian terpola dan membentuk kesatuan dunia secara utuh. Hal ini sesuai dengan pendapat Berger (2010: 28) yang menyatakan bahwa sesungguhnya simbolsimbol yang terdapat di dunia ini telah membantu manusia untuk tanggap terhadap sesuatu yang ada di sekelilingnya.

Cassirer mengajukan argumen bahwa sistem simbol merupakan satu-satunya elemen pokok yang secara fungsional dimiliki manusia untuk membedakannya dari binatang. Meskipun manusia dan binatang memiliki kesamaan indera dalam merespon stimulus dari luar, namun ada hal yang membedakan, yaitu bahwa "di antara sistem reseptor dan sistem efektor, yang terdapat pada semua spesies binatang, pada manusia terdapat mata rantai ke tiga yang mungkin dapat disebut sebagai sistem simbolis" (Cassirer, 1987: 38). Selanjutnya Cassirer menjelaskan bahwa dalam merespon semua rangsang yang ada, manusia tidak hanya melarutkan diri dalam dunia fisik sematamata, tetapi rangsangan tersebut membuat mereka hidup dalam dunia simbolis. Semua bentuk kehidupan seperti bahasa, religi, seni, dan mitos merupakan dunia simbolis yang membuat manusia hidup dalam dunia simbol yang sangat kompleks. Dalam kehidupan yang praktispun manusia tidak bisa hidup dalam dunia yang semata-mata bersifat fisis, tetapi juga dalam emosi imajiner; kerinduan; kecemasan; dan fantasi; yang di dalamnya melekat sistem simbol. Bahasa yang digunakan manusia untuk mengekspresikan 
gagasan dan perasaan-perasaan ini merupakan ekspresi afektif.

Gagasan Cassirer mengenai simbol ini mengandung penjelasan bahwa salah satu fungsi simbol dalam kehidupan manusia dalam hal-hal tertentu adalah untuk membuat benda-benda bisa 'berbicara' dan menghidupkan tanda-tanda material yang masih bersifat beku. Dengan simbol ini, maka ciri istimewa dari simbolisme manusia adalah bahwa semua yang ada di dunia ini mempunyai nama. Dalam menjelaskan hal ini, Cassirer mengajukan sebuah contoh kasus Hellen Keller yang bisu, tuli, dan buta yang secara mengejutkan ingin mengetahui nama-nama dari setiap benda yang ada di sekitarnya. Dari kasus ini Cassirer beragumen bahwa pada dasarnya setiap manusia selalu dapat membangun dunia simboliknya meskipun dengan segala keterbatasan instrumen yang dimiliki.

Dengan sistem simbol ini maka muncul 'ketergantungan pemikiran relasional kepada pemikiran simbolis'. Pada tahap ini manusia mengalami perkembangan pemikiran relasional dengan senantiasa menghubungkan segala sesuatu dengan simbol tertentu, yang tidak ditemui pada dunia binatang. Pemikiran relasional ini juga membuat manusia mampu menemukan makna makna yang abstrak tentang segala sesuatu. Sedangkan binatang tidak mampu mengembangkan distinctio rationis karena mereka tidak memiliki sistem simbol sebagai alat ucapan sebagaimana dimiliki manusia. Ekspresi simbolik dan kemampuan simbolik pada manusia merupakan indikator untuk mengetahui kemampuan manusia. Kemampuan simbolik manusia menunjukkan tipe pemikirannya, yang disebut Herder sebagai pemikiran reflektif. Cassirer (1987: 62) menyatakan bahwa tanpa dunia simbolik maka: "Hidup manusia akan terkurung dalam batas batas biologis dan kebutuhan praktisnya; tiada gerbang bagi dunia ideal, yang dari berbagai sisi dijanjikan oleh agama, kesenian, filsafat, dan ilmu pengetahuan". Ekspresi ini dibedakan menjadi dua bentuk, yaitu bentuk aesthetic sebagai ekspresi keindahan dan bentuk scientific sebagai ekspresi ilmiah atau pengetahuan..

\section{SIMBOL KEAGAMAAN}

Dengan menggunakan batasan simbol di muka, maka yang dimaksud dengan 'simbol keagamaan' dalam tulisan ini adalah semua atribut, gejala, dan atau penanda yang digunakan manusia untuk menunjukkan keberadaan serta ciri tertentu suatu agama, termasuk di dalamnya sistem nilai dan sistem kepercayaannya. Dalam teori sosial, disebutkan: "Religious symbols may embody or condense moods, feelings and values, but symbols may also refer to specific places, persons or events in history" (Turner, 1983: 
56). Jika ditinjau dari klasifikasi Beattie (1964) tentang pemaknaan manusia terhadap nilai-nilai simbolik, maka realisme simbolik dalam agama bisa berbenturan dengan praktek keagamaan yang dianut kelompok pengguna agama, karena praktek keagamaan dalam masyarakat bisa bervariasi sesuai dengan kelompok atau kelas sosial. Kelompok yang menamakan diri sebagai 'kelompok rasional' seperti masyarakat Amerika Serikat, misalnya, lebih mengutamakan sisi praktek keagamaan dibanding aspek simbolik agama (Turner, 1983: 56). Sementara pada masyarakat yang lain, praktek keagamaan bisa berjalan dengan cara yang berbeda sesuai dengan pola persepsi masyarakat tersebut terhadap nilai-nilai simbolik agama.

Dalam kaitannya dengan simbol keagamaan, Geertz (1973: 90) mengatakan bahwa agama adalah: "l) $a$ system of symbols which acts to 2) establish powerful, pervasive, and longlasting moods and motivations in men by 3) formulating conceptions of a general order of existence and 4) clothing these conceptions with such an aura of factuality that 5) the moods and motivations seem uniquely realistic”. Jika konsepsi Geertz (1973) yang menjelaskan bahwa agama merupakan sistem simbol ini dipadukan dengan konsepsi Turner tentang simbol (1982), serta konsepsi Berger (2010) tentang sifat konvensional sebuah simbol, maka bisa ditemukan sebuah rumusan bahwa penggunaan simbol keagamaan akan bervariasi sesuai dengan pola interpretasi para penganut agama tentang simbol tersebut.

Sedangkan menurut Berger (2010: 28), "simbol keagamaan selalu berada pada puncak gunung dari peristiwa bersejarah, legenda-legenda dan sebagainya dan memiliki kekuatan untuk mengarahkan pikiran" manusia. Sementara Geertz menekankan bahwa pada hakekatnya agama pasti menawarkan suatu pedoman hidup yang unik dan realistik bagi manusia, yang dirasakan dan dipersepsi secara berbeda antara satu kebudayaan dengan kebudayaan yang lain. Dengan adanya keunikan dan kerealistikan ini, maka bisa saja sebenarnya seseorang tidak menjadi relijius, tetapi karena dia hendak menemukan suatu makna hakiki, maka dia akan menggunakan simbolsimbol agama.

Dalam konteks simbol keagamaan dalam Islam, Ridwan (2004: 132) menjelaskan bahwa simbol-simbol tersebut merupakan sumber tekstual keagamaan yang berupa doktrin permanen sehingga tidak bisa diubah sesuai dengan perspektif para penafsir agama. Pendapat ini merupakan salah satu fenomena penolakan dari sebagian umat 
Islam terhadap metode tafsir hermeneutika yang mulai dilakukan oleh sebagian intelektual Muslim. Namun demikian, sifat teks keagamaan yang (menurut Ridwan) merupakan doktrin permanen serta penolakan terhadap metode penafsiran yang dianggap baru di kalangan umat Islam ini tidak cukup efektif untuk mencegah dinamika serta perubahan dalam penggunaan dan interpretasi terhadap simbol-simbol keagamaan yang terus berkembang.

Mengenai dinamika penafsiran terhadap simbol-simbol kegamaan di dalam ajaran Islam, Piliang (2003: 308) menjelaskan bahwa untuk mengkaji hal-hal tersebut yang berkaitan dengan komunikasi, maka diperlukan sebuah pemahaman bahwa agama memang menggunakan dua bentuk tanda, yaitu (1) tanda-tanda yang wajib diterima secara ideologis sebagai hal yang bersifat transenden, dan (2) tanda-tanda yang telah diterima secara sosial meskipun sesungguhnya tanda-tanda tersebut masih terbuka lebar bagi ruang interpretasi. Keaneka ragaman cara persepsi dan cara interpretasi terhadap simbol-simbol keagamaan yang besifat permanen menjadi salah satu penyebab munculnya beberapa aliran keagamaan dalam Islam baik yang berupa ormas maupun yang berupa jamaah.

Pola interpretasi yang berbeda-beda ini juga disebabkan oleh proses penyebaran ajaran Islam yang bersifat lintas kultural dimana para penyebar agama mencoba untuk beradaptasi dengan cara mengakomodasi budaya setempat ke dalam ajaran Islam, misalnya peristiwa penyebaran Islam di Jawa yang dilakukan oleh para wali yang dikenal dengan istilah Walisanga. Proses islamisasi di wilayah Jawa tidak bisa dilepaskan dari simbol mitologi serta simbol-simbol linguistik yang berkembang pada masyarakat Jawa (Berg, 1995: 134). Setidaknya proses islamisasi yang dilakukan oleh Sultan Agung juga tidak lepas dari pola interpretasi yang dilakukannya terhadap ajaran Islam dengan mengadopsi budaya setempat bisa dijadikan sebagai salah satu bukti formal. Akibatnya praktek keagamaan dalam masyarakat Jawa diwarnai dengan simbol-simbol ritual yang merupakan percampuran antara simbol Islam dan simbol budaya Jawa. Penggunaan simbol-simbol campuran ini menjadi identitas Islam di Jawa kurun waktu yang relatif panjang.

Jika proses penyebaran ajaran Islam ini dikembalikan kepada konsepsi Berger tentang sifat konvensional simbol (Berger, 2010: 29), maka dalam proses islamisasi di wilayah Jawa, simbol-simbol Islam telah diinterpretasikan terlebih dahulu oleh para penyebar ajaran sebelum disampaikan kepada masyarakat. Hasil interpretasi tersebut kemudian disampaikan kepada masyarakat yang kemudian ditafsirkan oleh masyakarat sesuai dengan pola konsumsi 
yang telah disesuaikan dengan budaya setempat serta pola persepsi individu. Akibatnya, setelah melalui proses penyebaran yang bersifat lintas kultural dan lintas negara serta proses interpretasi multi-tahap, simbol-simbol Islam tersebut banyak mengalami peristiwa konstruksi sosial serta konstruksi budaya, sehingga mengalami perubahan dan pergeseran makna dari ajaran aslinya. Oleh karena itu, sebagaimana tesis Geertz dan Berger, muncullah simbol keagamaan yang bersifat konvensionalkultural.

Argumen Geertz dan Berger ini hampir serupa dengan konsepsi Cassirer (1987: 111) yang menjelaskan bahwa pola pengamalan agama seseorang sangat berkaitan dengan perasaan keagamaan manusia yang tentunya memiliki bentuk-bentuk tertentu, dan bukan hanya ditentukan oleh dogma-dogma kepercayaan dan doktrin-doktrin serta sistem teologis semata. Hal ini berarti bahwa dalam dimensi pengamalan beragama, menusia menggunakan dua jenis simbol, yaitu (1) simbol-simbol yang bersifat doktriner teologis, dan (2) simbol-simbol yang bersifat sosio-kultural yang merupakan hasil interpretasi manusia terhadap simbol yang bersifat doktriner. Selanjutnya Cassirer berpendapat bahwa meskipun simbol-simbol keagamaan yang digunakan umat beragama bisa berubah-ubah sesuai dengan cara penafirannya, namun kegiatan simbolik keagamaan pada dasarnya tetap sama. Dengan kata lain, cara-cara ritual yang dilakukan umat beragama bisa berbeda-beda, meskipun mereka menganut agama yang sama dan menggunakan sumber yang sama.

\section{DUNIA TELEVISI}

Televisi diidentifikasi sebagai media komunikasi yang bersifat transitoris karena karakter dari volume materi yang ditawarkan kepada konsumen serta informasi yang sifatnya tidak permanen dan adanya proses perekaman dalam kegiatan tayangnya (Burton, 2007: 21). Meskipun informasi yang disampaikan bersifat tidak permanen, namun karena televisi memiliki karakter visual auditif maka tidak menutup kemungkinan bahwa pesan-pesan yang disampaikannya bisa menimbulkan efek tertentu bagi pemirsanya. Dengan mengambil teori madzab Frankfurt tentang 'selera konsumen', maka bisa dikatakan bahwa efek yang ditimbulkan oleh televisi sesungguhnya bukan semata-mata terletak pada jenis dan sifat pesan yang disampaikan tetapi lebih pada pola konsumsi yang dimiliki masyarakat.

Perlu digaris bawahi di sini bahwa televisi hanyalah salah satu dari banyak media yang menawarkan hiburan dan informasi yang memiliki hubungan interaktif dengan rumah produksi (production house) dan institusi informasi yang lain. Disamping 
fungsi hiburan, secara normatif televisi memiliki fungsi lain berupa pendidikan, fungsi persuasif, fungsi informasi, fungsi kontrol sosial, dan fungsi sebagai pewaris budaya. Fungsi-fungsi ini secara umum termanifestasikan dalam bentuk beberapa program seperti talk-show, iklan layanan masyarakat dan iklan komersil, berita, film dokumenter, film fiksi, serta program budaya. Meskipun demikian, programprogram yang ditayangkan televisi bisa saja bersifat overlap, misalnya, terjadinya campur aduk antara fungsi infromasi dan fungsi hiburan yang dalam prakteknya kadangkala materi hiburan yang disampaikan televisi bisa bersifat informatif, dan sebaliknya materi informasi bisa bersifat hiburan sehingga tidak mudah untuk membedakan antara pesan informasi dan pesan hiburan (Burton, 2007: 98). Sifat entertaining televisi pada umumnya terdapat pada televisi swasta yang memang memiliki karakter menonjol di bidang ini dengan lebih banyak menawarkan program yang bersifat hiburan, sehingga pesan-pesan informatif pun lebih sering dikemas dalam bentuk hiburan.

Disamping itu, kehidupan televisi swasta atau televisi komersial sangat tergantung kepada besar kecilnya iklan yang masuk, oleh karenanya, televisi menuntut adanya popularitas. Sedangkan popularitas tersebut bisa didapatkan dengan cara menghadirkan program-program populer yang ditujukan kepada masyarakat yang bersifat pasif yang memerlukan hiburan dan terkadang kurang bisa bersikap kritis. Untuk mengetahui popularitas program, maka televisi memiliki tingkat ketergantungan yang relatif tinggi terhadap hasil rating. Efeknya, untuk memperoleh popularitas serta perhatian masyarakat (audience) ini, secara logis televisi lebih banyak berkiblat pada ideologi kapitalis yang lebih mementingkan aspek keuntungan dibanding aspek sosiokultural, sehingga tidak menutup kemungkinan bahwa sebuah informasi bisa bersifat socially high cost. Logika kapitalis ini disamarkan oleh stasiun televisi yang membuat slogan berupa jingle yang seolaholah berfihak kepada kepentingan penonton, misalnya, Indosiar membuat slogan "Memang Untuk Anda" dan SCTV membuat slogan "Untuk Kita Semua". Meskipun televisi swasta menggunakan prinsip 'melayani kebutuhan masyarakat', namun terminologi "kebutuhan" itu dalam prakteknya hanya sebatas dimaknai sebagai "kebutuhan untuk diterima masyarakat" dalam rangka memperoleh penonton sebanyak-banyaknya yang tujuan akhirnya adalah menarik minat para pemasang iklan komersil.

Madzab Frankfurt (dalam Strinati, 2004: 89) melihat ada dua jenis kebutuhan masyarakat, yaitu 'kebutuhan sejati' dan 'kebutuhan semu' atau kebutuhan palsu. 
Dalam praktek kehidupan pada masyarakat kapitalistik, kebutuhan palsu masyarakat (yaitu kebutuhan yang bersifat konsumeris) yang bisa dijamin pencapaiannya oleh industri budaya seringkali bersifat menindas kebutuhan sejati (yaitu kebutuhan akan kebebasan dan kemandirian). Jika dilihat dari perspektif madzab ini, maka bisa dikatakan bahwa industri hiburan yang ditawarkan televisi rata-rata hanya menjual kebutuhan 'semu' masyarakat dan bukan kebutuhan untuk menyajikan informasi yang benarbenar diperlukan masyarakat atau kebutuhan sejati. Masyarakat kapitalis sekedar menjual apa yang hendak dibeli oleh konsumen dengan nilai imbalan yang sesuai dengan apa yang diperoleh oleh konsumen. Pada sisi yang lain, konsumen membayar dengan nilai sesuai dengan cost yang telah dikeluarkan. Kalau dilihat dari sisi hukum pasar maka proses jual beli atau proses produksikonsumsi dalam industri budaya ini didasarkan pada pola saling menguntungkan, dimana apabila konsumen sudah merasa tidak cocok lagi dengan produk budaya yang berkembang maka mereka memiliki hak individu untuk tidak menggunakan dan tidak mengkonsumsinya.

Dalam aspek kultural, televisi menganggap masyarakat adalah penonton yang memiliki karakter sebagai turis budaya, oleh karenanya televisi berusaha untuk memasukkan sebanyak mungkin unsur-unsur kebudayaan yang menjadi kebutuhan penontonnya. Pada sisi yang lain, setiap penonton memiliki cara tersendiri untuk mencari kesenangan dari televisi, dan televisi menangkap selera pasar ini dengan cara menghadirkan program yang populer untuk menggaet sebanyak mungkin pemirsa sebagai pencarian kultural (cultural pursuit) sehingga bisa meyakinkan pengiklan untuk memasarkan produknya (Burton, 2007: 96). Aspek kultural yang menjadi pertimbangan penting adalah 'unsur budaya apa yang paling digemari penonton dan mudah diterima keberadaannya' sehingga ia memiliki nilai jual yang cukup tinggi. Sedangkan aspek budaya yang ditawarkan oleh televisi pada umumnya telah mengalami proses interpretasi awal yang ditentukan oleh rating penonton yang tinggi. Ini artinya televisi menjual apa yang diinginkan oleh masyarakat -atau menurut definisi Storey tentang pop culture sebagai 'event yang digemari orang banyak untuk menghibur diri'-- sehingga televisi dengan sendirinya telah ikut menyebarluaskan budaya populer.

Dengan demikian, maka dalam pasar televisi yang kapitalis, aspek kebudayaan masyarakat hanya berperan sebagai obyek jual dan kemudian dipertimbangkan sebagai bahan materi tayangan. Yang menjadi pertimbangan utama pasar kapitalis adalah selera publik (konsumen) dengan prinsip demand and supply, karena dengan 


\section{Siti Solikhati}

memenuhi tuntutan masyarakat maka televisi akan dapat memenuhi tuntutan popularitas. Pada saat popularitas di mata masyarakat sudah terpenuhi, maka secara tidak langsung popularitas di mata pengiklan juga tercapai dan ideologi kapitalisme semakin terkuatkan.

Konsep popularitas serta ideologi kapitalis semakin melengkapi klaim yang mengatakan bahwa televisi merupakan salah satu bentuk budaya populer, yang dalam catatan Storey, telah muncul pada abad 20-an (Storey, 2007: 11). Berdasarkan tesis Storey ini, maka dalam wacana budaya populer, televisi bukan hanya dianggap semata mata sebagai 'agent of social changes', (John Fiske, 1978: 1) tetapi juga menjadi 'bagian' dari budaya populer itu sendiri. Dalam wacana perubahan sosial, televisi sering dipandang dan dituduh sebagai media yang mampu 'merubah' wajah dunia. Anggapan ini agak berlebihan karena berdasarkan konsep industri budaya sesungguhnya perubahan perubahan sosial tidak berjalan secara revolutif tetapi bersifat evolutif gradatif, serta tidak semata-mata disebabkan oleh substansi materi yang disampaikan televisi melainkan oleh pola konsumsi serta pola interpretasi konsumen. Pada struktur masyarakat kapitalis, peran televisi dalam masyarakat bisa dilihat dari sisi:

(1). informasi budaya, tentang apa yang disampaikan kepada masyarakat dan apa yang tidak disampaikan kepada masyarakat serta

(2). bagaimana pola konsumsi masyarakat.

Dalam pandangan ini, maka bisa dilihat bahwa dari struktur masyarakat kapitalis ini ada keterkaitan antara masyarakat dan industri budaya yang ada di dalamnya, dimana industri budaya yang terjadi dalam masyarakat ditangkap kemudian disebarluaskan melalui televisi dan dikonsumsi kembali oleh masyarakat. Dengan demikian maka bisa dikatakan bahwa secara kultural, televisi lebih banyak berperan sebagai 'makelar budaya' sedangkan yang berperan sebagai produsen sekaligus konsumen budaya adalah masyarakat itu sendiri. Sebagai makelar budaya, televisi tentu saja menggunakan hukum pasar dengan hanya membeli dan menjual kembali produk yang laku di pasaran.

\section{REPRESENTASI SIMBOL KEAGAMAAN DI TELEVISI}

Sebelum menjelaskan tentang representasi simbol keagamaan, terlebih dahulu penulis perlu memaparkan apa yang dimaksud dengan terminologi representasi dalam tulisan ini. Piliang (2010: 21) mendefinisikan representasi sebagai "tindakan menghadirkan atau mempresentasikan sesuatu lewat sesuatu yang lain di luar dirinya, biasanya berupa tanda atau 
simbol”. Representasi merupakan sebuah proses pencitraan tentang sesuatu dimana citra yang dimunculkan tidak menggambarkan realitas yang sesungguhnya. Melalui politik representasi atau politik pencitraan, oleh karena itu, bisa dikatakan bahwa sesuatu hendak digambarkan sesuai dengan keinginan pembuat citra untuk menimbulkan efek tertentu untuk menciptakan ideologi dominan. Sebuah stasiun televisi bisa saja menyampaikan program acara keagamaan yang menggambarkan sebuah kegiatan keagamaan dengan menggunakan simbol-simbol tertentu, padahal sebenarnya fakta keagamaan tidak selalu tampak sebagaimana yang dihadirkan dalam program tersebut. Menurut Hall (2011: 218) hal ini merupakan salah satu efek teknis dalam peristiwa representasi karena tanda-tanda yang disampaikan melalui televisi merupakan tanda yang berifat kompleks yang merupakan tanda visual dan tanda auditif.

Sedangkan Ehrat (2005: 4-5) menjelaskan bahwa dalam sebuah program televisi yang berbentuk sinetron atau film, representasi tentang sesuatu bisa dilihat dari adanya hubungan saling keterkaitan yang terdapat pada tiga area permasalahan yaitu: (1) wilayah meaning atau makna, yang bisa dilihat dari kode-kode yang digunakan dalam film, (2) narasi yang berkaitan dengan waktu, dimana narasi dalam film hanya merupakan sebuah imitasi dari perilaku dan oleh karena itu perlu dipertanyakan kebenarannya dan (3) estetika, dimana aspek seni merupakan salah satu problem dalam memahami makna film. Sebagai salah satu bentuk dari karya seni, pemaknaan terhadap sebuah film bisa memunculkan berbagai wacana yang berbeda, karena kreativitas seni terkadang memunculkan hal-hal yang di luar imaginasi.

Dalam pembahasan mengenai representasi Islam dengan menggunakan simbol-simbol keagamaan dalam film (sinetron), penulis mengadopsi struktur perangkat analisis yang dibuat Fiske (1987) yang melibatkan tiga level pemaknaan dalam memahami kode-kode televisi. Struktur Fiske menjadi faktor penting dalam penelitian ini karena perangkat semiotik yang ditawarkannya bisa menjawab persoalanpersoalan dalam penelitian ini, mulai dari persoalan representasi hingga ideologi televisi. Fiske mengajukan argumen bahwa sebuah kejadian atau realitas yang ditayangkan di televisi sebelumnya telah melalui proses encoding sesuai dengan kodekode sosial sebagaimana kode yang diberlakukan oleh televisi. Dalam hal ini kode dimaknai oleh Fiske sebagai seperangkat aturan dari sistem tanda yang telah disepakati dalam sebuah komunitas tertentu yang digunakan untuk menyebarkan makna. Secara semiotis, melalui politik representasi 
televisi menciptakan makna di tengah berbagai kalangan masyarakat dengan cara menghadirkan sesuatu untuk memenuhi kepentingan dominan di masyarakat, serta menyebarkan makna tersebut kepada pemirsanya.

Selanjutnya Fiske (1987: 4) membuat struktur pemaknaan tentang kode-kode televisi sebagai berikut:

Level 1

\section{Realitas}

Penampilan, busana, make-up, perilaku, pembicaraan (kata-kata) gestur, ekspresi, suara

(Yang di-encode secara elektronik menggunakan kode teknis tertentu dalam wujud)

Level 2

\section{Representasi}

Kamera, lighting, editing, musik, suara

(Yang membentuk representasi seperti naratif, konflik, tindakan, karakter, dialog, setting, casting)

Level 3

\section{Ideologi}

Individualisme, patriarki, ras, kelas sosial, materialisme, kapitalisme

(Yang disusun ke dalam penerimaan sosial yang koheren oleh kode-kode ideologis).

Dalam kajian terhadap film (sinetron), penggunaan simbol-simbol tertentu dalam merepresentasikan sebuah realitas merupakan sebuah kesengajaan untuk menciptakan citra tertentu. Dalam hal ini Fiske (1987: 21) menjelaskan bahwa televisi adalah media yang realistik karena ia mampu menumbuhkan keyakinan sosial di kalangan pemirsa tentang hal-hal yang bersifat riil. Fiske menyebut hal itu sebagai realism yang difahami sebagai bentuk narasi tertentu, meskipun narasi itu beruwjud gambar dan lukisan. Selanjutnya Fiske mengatakan bahwa "realism is not a matter of any fidelity to an empirical reality, but of the discursive convention by which and on which a sense of reality is constructed" (Fiske, 1987: 23). Melihat pada konstruksi realitas yang disebutkan Fiske ini, maka dapat dikatakan bahwa program-program fiksi yang ditawarkan televisipun pada hakekatnya merupakan hal yang bersifat realistik. Kemampuan televisi dalam menghadirkan realitas yang dapat diterima khalayak sesuai dengan kode-kode sosial yang berlaku secara tidak langsung telah menjadikan televisi sebagai media yang strategis untuk menyebarkan berbagai jenis informasi.

Posisi strategis televisi sebagai agen transformasi budaya menjadikannya sebagai salah satu media yang dipilih umat Islam untuk proses penyebaran ajaran agama. Sejalan dengan berkembangnya tuntutan komunitas umat Islam akan perlunya media guna mengembangkan ajaran agama, maka 
televisi merupakan alernatif yang sulit untuk dihindarkan. Konsekuensi dari perlunya televisi dalam kegiatan pengembangan ajaran Islam ini adalah bahwa kegiatan keagamaan yang bersifat privat dan sakral secara tak terhindarkan lagi harus memasuki wilayah publik dan profan. Dalam pengantar buku Media dan Citra Muslim, Ibrahim (2005) menekankan bahwa ekspresi sikap keberagamaan umat Islam di Indonesia pada masa kini telah benar-benar menemukan aktualisasinya dalam ruang publik melalui media massa. Namun demikian semua ekspresi simbol-simbol keagamaan yang ditransformasikan lewat media massa tersebut pada dasarnya bukan lagi merupakan representasi bentuk murni dari simbol-simbol doktriner agama melainkan lebih merupakan hasil konstruksi sosial yang bertarung dalam praktik kinerja media. Hal ini bisa difahami karena penghadiran simbolsimbol keagamaan dalam tayangan televisi tidak bisa dibatasi hanya pada wilayah yang bersifat sakral saja.

Pemahaman ini sesuai dengan hasil penelitian Maguire dan kawan-kawan (2013) mengenai sekularisasi agama dan televisi komersial yang dilakukan terhadap tayangan televisi di Amerika. Dalam hasil penelitian ini disebutkan bahwa "religious symbolism is not restricted to a special sacred sphere, but can be found in any number of social contexts and social mediums -- including, presumably, television". Hal ini mengindikasikan bahwa representasi agama dengan menggunakan simbol-simbol keagamaan dalam tayangan televisi bukan pekerjaan yang sederhana, karena simbolsimbol tersebut tidak semata-mata digunakan untuk menyam-paikan pesan keagamaan semata, namun juga untuk kepentingan sosial serta media itu sendiri.

Ketika simbol keagamaan direpresentasikan dalam bentuk pesan di media televisi, maka ia memberi kesempatan kepada siapa saja untuk melakukan penafsiran dan pemaknaan. Proses penafsiran ini tentu saja berbeda-beda antara satu orang dengan yang lainnya, sebagai akibat dari perbedaan kerangka acuan dan sistem kepercayaan. Disamping itu, proses penafsiran terhadap pesan-pesan keagamaan juga dipengaruhi oleh bagaimana proses pesan yang bersifat simbolik itu diproduksi. Proses penafsiran simbol-simbol keagamaan yang dilakukan melalui beberapa tahap, sebagaimana telah dijelaskan pada bagian sebelumnya, mengakibatkan wacana penafsiran simbol keagamaan sebagai bentuk pesan media menjadi semakin kompleks, karena proses yang dilaluinya memungkinkan terjadinya bias. Perubahan wacana serta perubahan bentuk simbol-simbol keagamaan ini semakin beragam sebagai akibat campur tangan media massa dalam proses penyebaran pesan-pesan keagamaan. 
Akibatnya, simbol-simbol keagamaan tercampur aduk dengan produk budaya populer media massa yang menggunakan logika keseragaman, sehingga memunculkan simbol keagamaan yang bersifat kultural dan nyaris seragam. Oleh Irianto (dalam Ibrahim, 2005: 520), penggambaran tentang agama (Islam) di media massa (khususnya televisi) pada hakekatnya tidak merefleksikan ajaran yang sesungguhnya, karena ia lebih mengutamakan tampilan fisik dengan menggunakan simbol-simbol yang mendekati citra Islam.

Kehidupan keberagamaan seseorang sesungguhnya tidak hanya diwujudkan dalam bentuk penggunaan simbol dan atribut kegamaan, tetapi juga dalam bentuk sikap dan perilaku religius. Oleh karena itu untuk menggambarkan Islam secara kontekstual, perlu dilakukan kajian yang teliti mengenai penggunaan simbol-simbol keagamaan tersebut. Dalam konteks penelitian ini, simbol-simbol keagamaan (Islam) dibedakan menjadi dua kelompok yaitu:

(1) simbol secara normatif yang dibatasi pada keberadaan ayat al Qur'an serta hadits nabi yang merupakan simbol dari doktrin keagamaan

(2) simbol secara kultural akibat pola tafsir dan konstruksi sosial yang berupa sikap dan perilaku beragama pemeluk
Islam serta atribut keagamaan yang digunakan oleh umat Islam.

Pembedaan ini didasarkan pada pendapat Cassirer mengenai bentuk-bentuk simbol keagamaan yang meliputi perasaan keagamaan serta doktrin keagamaan sebagaimana telah dijelaskan di muka.

Konstruksi simbol-simbol keagamaan (Islam) yang dihadirkan televisi menjadi semakin rumit karena media tersebut menggunakan parameternya sendiri, yang tidak selamanya bisa berjalan seimbang dengan parameter Islam. Mengenai deskripsi kerumitan proses produksi pesan komunikasi melalui media ini, Morley (dalam Storey, 2007: 17) menjelaskan bahwa setidaknya ada tiga hal yang perlu dicermati, yaitu:

1. Produksi pesan merupakan pekerjaan yang problematik, karena satu peristiwa bisa di-encode dengan cara yang berbeda oleh pembuat pesan, sehingga ketika sampai pada decoder, pesan tersebut bisa menghasilkan makna yang berbeda

2. Pesan komunikasi yang dibuat oleh media bersifat teks terbuka yang memungkinkan untuk dimaknai secara berbeda oleh penerima pesan

3. Peristiwa decoding merupakan proses yang problematik karena satu pesan bisa dimaknai dengan cara 
yang berbeda oleh orang yang berbeda

Teori sosial yang berkembang tentang paradigma konstruksi sosial di media ini diawali oleh sebuah asumsi bahwa pada hakekatnya manusia itu dianggap sebagai aktor yang kreatif (Bungin, 2001: 5). Kreativitas manusia ini diwujudkan dengan berbagai kemampuan yang dimilikinya untuk membuat konstruk atas realitas sosial yang ada, yang kebenarannya bersifat relatif. Sedangkan relativitas dari realitas sosial ini dibentuk oleh adanya konvensi-konvensi atau kesepakatan yang berlaku pada masyarakat setempat, serta tergantung pada waktu dan tempat realitas sosial tersebut diberlakukan. Oleh karena itu realitas sosial juga bisa dikatakan sebagai hasil atau produk dari sebuah konstruksi sosial.

Paradigma komunikasi yang memberikan kontribusi cukup besar dalam kajian penggunaan simbol di media massa adalah konsep linguistik yang disumbangkan Jacobson (dalam Fiske, 1987 b: 47). Dalam paradigma ini Jacobson menengahi paradigma komunikasi linear yang dikembangkan Shannon dan Weaver yang berseberangan dengan paradigma komunikasi triangular yang dikembangkan Newcomb pada pertengahan abad ke 20 . Perspektif linguistik Jacobson mengatakan bahwa sebuah pesan (teks) baru akan bisa berbicara atau mengandung makna ketika pesan tersebut dilihat dari tiga sisi, yaitu:

(a) context (konteks sosial, atau dalam kaitan apa serta kapan dan di mana pesan tersebut digunakan), artinya sebuah pesan bisa saja memiliki makna atau dimaknai secara berbeda apabila pesan tersebut digunakan dalam konteks sosial yang berbeda

(b) contact (hubungan antara pengirim dan penerima pesan), artinya sebuah pesan juga bisa dimaknai secara berbeda tergantung pada intensitas hubungan serta jarak psikologis (psychological gap) antara pengirim dan penerima pesan

(c) code (simbol yang digunakan), artinya bahasa pesan atau tanda (ikon, simbol) baik itu verbal ataupun non verbal juga berpengaruh terhadap proses pemaknaan sebuah pesan.

Salah satu bentuk simbol keagamaan yang sudah mengalami proses konstruksi yang dihadirkan televisi adalah sinetron religi. Terminologi "sinetron" pada umumnya dipahami sebagai kependekan istilah dari sinema elektronik yang merupakan cerita bersambung yang secara khusus ditayangkan di televisi. Sinetron pada dasarnya merupakan duplikasi opera sabun yang ditayangkan oleh televisi asing, 


\section{Siti Solikhati}

sedangkan istilah sinetron secara khusus diberlakukan di Indonesia sebagaimana ungkapan Arimbi "Sinetron is an Indonesian term for soap opera in television. It is an acronym for cinema electronic" (Arimbi, 2009: 202). Sedangkan menurut Endah (2008) sinetron merupakan kepanjangan dari sinema elektronik yang berarti sebuah karya cipta seni budaya, dan media komunikasi pandang dengar yang dibuat berdasarkan sinematografi dengan direkam pada pita video melalui proses elektronik lalu ditayangkan melalui stasiun televisi. Istilah sinetron ini pertama kali di Indonesia dipopulerkan Arswendo Atmowiloto.

Untuk memahami bagaimana Islam direpresentasikan menggunakan simbolsimbol keagamaan dalam bentuk tayangan televisi yang bernuansa hiburan sebagaimana sinetron, maka diperlukan sebuah studi kritis yang menurut Burton (2007: 37) bisa dilakukan dengan menggunakan beberapa konsep kunci, yaitu dengan melihat pada ideologi, konsep komodifikasi, representasi, dan modus penyampaian pesan. Oleh karena representasi agama sudah dijadikan komoditas dagangan oleh pihak media sebagaimana telah dijelaskan di muka, maka Burton melemparkan gagasan mengenai bagaimana sebuah pesan (dalam konteks tulisan ini berupa ajaran Islam) direpresentasikan menggunakan kode-kode televisi yang bersifat kultural sehingga membentuk citra tertentu, karena agama adalah salah satu wilayah kultural. Dalam setiap realitas ajaran keagamaan selalu terdapat ikon, simbol, dan sistem tanda yang perlu dipahami strukturnya. Pada sisi lain, realitas keagamaan yang dihadirkan ke hadapan pemirsa televisi sudah berwujud 'realitas bentukan' atau realitas citraan karena realitas tersebut telah mengalami konstruksi serta modifikasi melalui politik representasi. Upaya untuk melihat bagaimana simbolsimbol keagamaan dihadirkan dalam bentuk hiburan di televisi setidaknya bisa membantu menemukan tiga hal:

(a) untuk menemukan inti pesan berupa ajaran keagamaan yang merupakan realitas media,

(b) untuk melihat bagaimana representasi dari wujud pesan tersebut dalam bentuk simbol keagamaan, dan

(c) untuk menemukan ideologi yang tersembunyi di balik penggunaan simbol-simbol keagamaan.

Apabila melihat tesis Adorno (dalam Strinati, 2004: 89) maka penulis beranggapan bahwa kebutuhan manusia akan kehidupan beragama sesungguhnya merupakan kebutuhan sejati sedangkan kebutuhan akan hiburan adalah kebutuhan semu yang bersifat temporer. Berdasarkan argumen ini maka 
masuknya kepentingan penyebaran ajaran Islam melalui televisi yang sudah masuk dalam wilayah budaya populer ini bisa diibaratkan dengan terjalinnya sintesa antara kebutuhan sejati dan kebutuhan semu yang melahirkan wajah dan pola beragama yang semu atau pola beragama citraan. Dalam praktek produksi dan konsumsi pesan atau simbol-simbol ajaran Islam melalui televisi, peristiwanya menjadi rumit karena tiga hal, yaitu: Pertama, dalam proses produksi informasi, pesan atau simbol-simbol ajaran keagamaan (Islam) yang berupa doktrin yang bersifat permanen telah terlebih dahulu mengalami sebuah interpretasi oleh produsen pesan. Dalam produksi pesan ini, paling sedikit ada dua tahapan interpretasi, karena produsen pesan (televisi) pada umumnya bukan merupakan sekelompok individu yang memperoleh ajaran Islam secara langsung dari sumber ajaran, melainkan melalui sumber ke dua atau bahkan ke tiga. Ke dua, sumber yang dijadikan rujukan media (televisi) telah melakukan interpretasi awal terhadap ajaran Islam. Ke tiga, rujukan pesan yang sudah mengalami peristiwa multiinterpretasi tersebut dihadirkan kepada pemirsa dengan dibumbui oleh campur tangan kepentingan pasar, yang kemudian diinterpretasikan lagi oleh pemirsa sesuai dengan pola konsumsi mereka. Peristiwa multi-interpretasi dalam produksi dan konsumsi pesan ini disebut dengan encoding dan decoding yang merupakan sebuah keniscayaan dalam praktek produksi dan konsumsi pesan televisi, dan membuat sintesa ini semakin menarik untuk didiskusikan.

Menurut Hall (2011: 213-214 dan dalam Storey, 2007: 17), model decoding dan encoding pesan televisi merupakan sirkuit dalam komunikasi massa yang melibatkan proses produksi-distribusi-produksi pesan yang berjalan sebagai berikut:

1. Produksi pesan penuh makna dalam wacana televisi senantiasa merupakan pekerjaan problematis. Peristiwa yang sama bisa diencoding melalui lebih dari satu cara, sehingga kajian televisi di sini berkenaan dengan bagaimana dan mengapa struktur dan praktek produksi tertentu cenderung menghasilkan pesan tertentu, yang mewujudkan maknanya dalam bentuk bentuk tertentu yang berulang.

2. Produk yang penuh makna tersebut didistribusikan oleh media dalam bentuk diskursif. Pesan dalam komunikasi sosial selalu bersifat kompleks dalam hal struktur dan bentuk. Ia senantiasa memuat lebih dari satu pembacaan potensial. Pesan menawarkan dan 
menganjurkan pembacaan tertentu atas pembacaan lainnya, namun pesan tidak pernah bisa menjadi sama sekali tertutup di sekitar satu pembacaan. Pesan tetap bersifat polisemik.

3. Diskursus tersebut diterjemahkan dalam praktek sosial oleh khalayak yang berbeda-beda dengan cara tafsir yang berbeda pula. Aktivitas mimetik makna dari pesan juga merupakan sebuah praktek yang problematis, betapapun transparan dan natural tampaknya aktivitas itu.

Sintesa antara proses penyebaran ajaran Islam dengan proses produksi serta konsumsi pesan di televisi disebabkan adanya semacam ketergantungan umat Islam terhadap kehadiran media ini. Ketergantungan umat Islam terhadap televisi sebagai salah satu media untuk penyebaran ajaran Islam terjadi karena adanya tuntutan beban normatif yang berupa kewajiban yang disandang umat Islam untuk menyebarkan ajaran agama sebagaimana disebutkan dalam surat an-Nahl ayat 125 yang berbunyi:

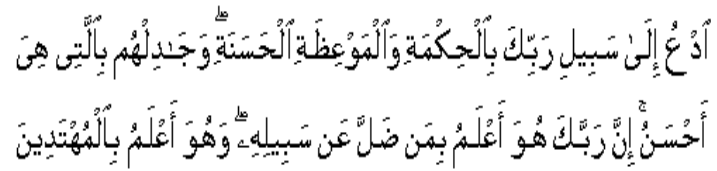

Artinya: "Ajaklah ke jalan Tuhanmu dengan hikmah dan pelajaran yang baik, dan bantahlah mereka dengan cara yang baik. Sesungguhnya Tuhanmu, Dialah yang lebih mengetahui siapa yang tersesat dari jalan-Nya, dan Dialah yang lebih mengetahui orang-orang yang mendapat petunjuk" (Depag. R.I., 1994: 421).

Terminologi hikmah di dalam tulisan ini dimaknai sebagai cara yang 'bijak' dengan jalan menyesuaikan konsep ajakan atau dakwah tersebut dengan kondisi masyarakat. Oleh karena itu penggunaan televisi sebagai salah satu media penyebaran ajaran Islam bisa diasumsikan sebagai bentuk respon dari para penyebar agama terhadap kebutuhan masyarakat saat ini. Dengan demikian maka logika masuknya wilayah kebutuhan agama atau sektor private ke dalam wilayah budaya populer ini, setidaknya ada empat alasan yang bisa penulis jelaskan, yaitu:

1. Umat Islam menyandang beban kewajiban untuk senantiasa menyebarkan ajaran Islam kepada orang lain. Sementara penyebaran ajaran yang dilakukan secara konvensional dengan ceramah dan pengajian sudah saatnya dilengkapi dengan media modern.

2. Televisi yang sampai saat ini masih dianggap sebagai media yang 
praktis dan bisa menjangkau khalayak luas merupakan alat yang prospektif untuk membantu umat Islam memenuhi tuntutan tersebut.

3. Karakter pesan televisi yang bersifat universal telah menyebarkan budaya yang sebagian dianggap sebagai ancaman yang bisa merusak moral manusia, sehingga umat Islam merasa perlu untuk mengimbangi budaya tersebut dengan informasi keagamaan. Dengan kata lain, hal ini dilakukan sebagai wujud counter product terhadap budaya yang dianggap kurang sesuai dengan ajaran Islam,

4. Kemajuan teknologi informasi yang sudah menjadi bagian dari budaya masyarakat menuntut umat Islam untuk menggunakan televisi sebagai media penyebaran ajaran Islam guna mengejar kemajuan tersebut.

Kondisi yang dialami umat Islam ini kemudian ditangkap oleh televisi sebagai peluang pasar yang baik. Hanya saja, penggunaan televisi sebagai salah satu media penyebaran ajaran Islam ini telah menimbulkan efek yang dilematis bagi umat Islam. Sedangkan menurut penulis, efek yang ditimbulkan oleh proses ini setidaknya ada dua yaitu (1) bahwa masuknya agama ke wilayah publik ini telah mengakibatkan popularisasi agama dan (2) munculnya bisnis informasi dengan menggunakan obyek simbol-simbol keagamaan sebagai barang dagangan. Namun demikian, tentu saja efek negatif tersebut merupakan salah satu konsekuensi logis dalam dunia komunikasi massa, dimana produk media senantiasa beredar melalui proses multi-interpretrasi sebagai akibat adanya peristiwa decoding dan encoding. Disamping itu, apabila terjadi distorsi dalam menghadirkan citra Islam dengan menggunakan simbol-simbol keagamaan dalam produksi televisi, hal ini merupakan tanggungjawab bersama antara produser pesan tersebut serta penyebar ajaran yang dijadikan rujukan media sebagai pihak yang bertanggung jawab atas produksi pesan. Hal ini sesuai dengan salah satu karakter media massa dimana sifat komunikator (produsen pesan) adalah melembaga (institutionalized) dan oleh karenanya produksi pesan tersebut merupakan hasil kolektif serta tanggung jawab kolektif.

\section{IDEOLOGI TELEVISI}

Dalam Collin Cobuild (1987: 718) terminologi ideologi didefinisikan sebagai " $a$ belief or a set of beliefs, especially the political beliefs on which people, parties, or countries base their actions". Kata ideologi yang berasal dari teori marxis dimaknai oleh Thwaites sebagai "ide yang dipegang bersama oleh kelompok sosial dalam 
kehidupan sehari-harinya" (Thwaites, 2009: 233). Ideologi merupakan logika ide yang mengindikasikan bahwa komunitas tertentu yang memegang ideologi tersebut secara sosial bersifat konsisten dalam mempersepsi serta memahami dunia dengan cara-cara tertentu yang telah disepakati. Sementara Althuser (dikutip dalam Fiske, 2007: 240) melihat ideologi bukan sebagai sebuah gagasan, melainkan sebuah praktik yang dilakukan secara sadar oleh semua kelompok dalam masyarakat, tanpa ada pihak yang memaksakan. Dengan demikian bisa dipahami bahwa ideologi bukan hanya merupakan cara pandang mengenai hal tertentu dalam sebuah komunitas tertentu, melainkan juga cara menyikapi kehidupan yang dipraktekkan dalam bentuk perilaku.

Dalam menjelaskan tentang ideologi Fairclough mengasumsikan bahwa ideologi ada keterkaitannya dengan kekuasaan "ideology is representation which contributes to the constitution, reproduction, and transformation of social relations of power domination" (dalam Larsen, 2006: 23). Gagasan tentang ideologi sebagai dominasi kekuasaan juga dilontarkan Kellner (2010: 83) dengan menjelaskan bahwa ideologi merupakan "bagian sebuah sistem penguasaan yang berperan melanggengkan penindasan dengan mengabsahkan berbagai daya dan lembaga yang menekan dan menindas orang".
Ideologi ini telah menjadi wilayah kajian utama dalam studi budaya. Selanjutnya dalam kajian studi budaya, pembahasan tentang ideologi dikembangkan dalam kaitannya dengan praktek wacana atau diskursus. Meskipun terdapat unsur power domination, namun ideologi yang terkandung dalam sebuah praktek wacana bisa menjadi sangat efektif sebagai alat kontrol sosial jika ia telah dinaturalisasikan dan telah menjadi sebuah common sense. Artinya bahwa ideologi yang telah diterima menjadi sebuah konvensi sosial bisa dianggap bukan lagi sebagai sesuatu yang mengandung unsur penindasan sebagaimana dikemukakan Kellner. Ketika membincangkan ideologi yang telah menjadi konvensi sosial ini, maka gagasan Althusser bahwa ideologi merupakan sebuah praktik menjadi hal yang menarik untuk diterapkan dalam penelitian ini. Ideologi bisa termanifestasikan dalam wujud sistem strata sosial, sistem politik, sistem ekonomi, serta sistem budaya.

Dalam sebuah tayangan film atau sinetron sebagai salah satu produk budaya, menurut Fiske (1987) ideologi yang terkandung di dalamnya bisa dilihat dari bagaimana simbol-simbol (baik yang bersifat verbal maupun non-verbal) digunakan, dari pemilihan para pemain atau bintang, serta pengaturan teknik kamera. Hal ini meliputi penentuan busana yang dikenakan para 
pemain, cara pengambilan gambar, serta cara merepresentasikan hubungan antar pemain. Dalam keterkaitan antara ideologi dengan representasi, ada kemiripan antara argumen yang dikemukakan Fairclough dengan Fiske. Ketika ideologi televisi dalam menayangkan sebuah film atau sinetron bisa diketahui dari cara penggunaan simbolsimbol, artinya bahwa ideologi juga bisa disebarkan melalui rekayasa komunikasi.

Rekayasa pesan-pesan komunikasi yang terjadi dalam produksi televisi tidak bisa dilepaskan dari karakter media tersebut yang menurut Burton (2007: 19-20) memiliki dua sifat penting, yaitu: (1) bersifat intertekstualitas dengan memanfaatkan peluang pasar dalam rangka mengejar rating yang tinggi, dan (2) bersifat polisemik yang menimbulkan peluang untuk terjadinya multi interpretasi di kalangan pemirsa. Manifestasi dari sifat intertekstualitas televisi terlihat dalam bentuk dorongan yang kuat untuk mengejar rating dan persaingan pasar, sehingga televisi menggunakan berbagai cara untuk memformulasikan program dengan teknik-teknik tertentu untuk membangun sebuah versi tentang 'yang real', meskipun semua program tersebut hanya berupa versi buatan yang berbeda mengenai hal yang real tersebut.

Selanjutnya Burton (2007: 20) menjelaskan bahwa yang dimaksud dengan sifat polisemik televisi adalah televisi terdiri dari banyak tanda yang dibangun menggunakan serangkaian kode-kode visual, kode verbal, kode teknikal, dan kode nonverbal. Ada dua pandangan yang ditawarkan Burton mengenai sifat polisemik televisi ini, yaitu: (1) polisemi bisa mengakibatkan munculnya banyak makna bagi khalayak akibat berbedanya pola pemaknaan, dan (2) televisi memiliki kekuatan untuk mengatur makna citra dan menggunakan strategi naratif yang mengarahkan khalayak agar memahami citra tersebut dengan cara tertentu.

\section{PENUTUP}

Secara teoretis televisi merupakan sarana komunikasi yang memiliki multi fungsi ideal sebagai alat penyebar informasi, hiburan, pendidikan, persuasi, dan kontrol sosial. Meskipun demikian televisi memiliki dimensi lain yang lebih bersifat praksis, yaitu sebagai instistusi bisnis hiburan, yang oleh karenanya televisi tidak berada di ruang hampa kepentingan bisnis kapitalis. Tidak terlalu mengejutkan bila agama dengan kompleksitas simbol-simbolnya menimbulkan wacana tersendiri ketika dihadirkan dalam media ini. Dalam konteks paper ini ini penulis melihat adanya sifat multi dimensi televisi dari sisi kepentingan produsen, yaitu dengan melihat sisi kekuatan institusi televisi dalam menggiring pola pemaknaan serta pola konsumsi masyarakat 
dengan cara tertentu yang disesuaikan dengan budaya televisi. Yang dimaksud dengan kepentingan di sini adalah kecenderungan televisi dalam menjangkau pasar dengan menggunakan logika kejar tayang. Dengan demikian jika sifat multi dimensi televisi ini dikaitkan dengan produksi program hiburan, maka alur pemikiran produksi tersebut bisa dijelaskan sebagai berikut.

1) memproduksi program sebanyak-banyaknya,

2) dengan menggunakan logika sederhana sehingga mudah dicerna oleh khalayak,

3) tidak memerlukan proses pemaknaan yang rumit,

4) menggunakan teknik representasi sedemikian rupa sehingga menjadi program yang menarik dan menghibur

\section{DAFTAR PUSTAKA}

Arimbi, D.A. (2009). Representation, Identity and Religion of Muslim Women in Indonesian Fiction. Amsterdam: ISAC.

Baudrillard, J. P. (2011). Masyarakat Konsumsi (terj. Wahyunto). Yogyakarta: Kreasi Wacana.

Berger, A. A. (2010). Pengantar Semiotika: Tanda-tanda Dalam Kebudayaan Kontemporer. (terj. M. Dwi Marianto). Yogyakarta: Tiara Wacana.
Berger, C. R., M. E. Rollof, D. R. Roskos, Ewoldsen (2014). Handbook Ilmu Komunikasi (terj. Derta Sri Widowatie). Bandung: Nusamedia.

Berger, P. and T. Luckman (1966). The Social Construction of Reality. USA: Penguin.

Broos, A. D. J. (1987), Creating Culture: Profiles in the Study of Culture. Sydney: Allen Unwin.

Bungin, B. (2001). Imaji Media Massa: Konstruksi dan Makna Realitas Sosial Iklan Televisi dalam Masyarakat Kapitalistik. Yogyakarta: Jendela.

Cassirer, E. (1987). Manusia dan Kebudayaan: Sebuah Esei Tentang Manusia. (terj. Alois A. Nugroho). Jakarta: Gramedia.

Cobuild, C. (1987). English Language Dictionary. London: Collin Publisher.

Danesi, M. (2010). Pesan, Tanda, dan Makna: Buku Teks Dasar Mengenai Semiotika dan Teori Komunikasi (terj. Evi Setyarini dan Lusi Lian Piantari). Yogyakarta: Jalasutra.

Donnan, H. (2002). Interpreting Islam. London: Sage.

Ehrat, J. (2005). Cinema and Semiotic: Peirce and Film Asthetic, Narration and Representation. Toronto: University of Toronto Press.

Endah (2008). "Sinetron sebagai Media Dakwah" (makalah tidak diterbitkan).

Fairclough, N. (1995). Media Discourse. London: Edward Arnold.

Fiske, J. (1987). Tevelevion Culture: Popular Pleasure and Politics. Britain: Cornell. 
Hall, S., D. Hobson, A. Lowe, P. Willis (2001). Budaya Media dan Bahasa: Teks Utama Pencanang Cultural Studies 1972-1979 (terj. Saleh Rahman). Yogyakarta: Jalasutra.

Hartley, J. (2010). Communication, Cultural, and Media Studies: Konsep Kunci (terj. Kartika Wijayanti). Yogyakarta: Jalasutra

Hill, J. D. and D. Whistler (2013). The Right To Wear Religious Symbols. England: Palgrave Macmillan.

Ibrahim, I. S. (2005). Media dan Citra Muslim, dari Spiritualitas untuk Berperang menuju Spiritualitas untuk Berdialog. Yogyakarta: Jalasutra.

Ibrahim, I. S. (2007). Budaya Populer Sebagai Komunikasi: Dinamika Popscape dan Mediascape di Indonesia Kontemporer. Yogyakarta: Jalasutra.

Kellner, D. (2010). Budaya Media: Cultural Studies, Identitas, dan Politik: Antara Modern dan Postmodern (terj. Galih Bondan Rambatan). Yogyakarta: Jalasutra.

Liliweri, A. (2011). Komunikasi Serba Ada Serba Makna. Jakarta: Prenada Media.

Majid, N. (1995). Islam Doktrin dan Peradaban: Sebuah Telaah Kritis tentang Masalah Keimanan, Kemanusiaan, dan Kemoderenan. Jakarta: Yayasan Paramadina.

Piliang, Y. A. (2003). Hipersemiotika: Tafsir Cultural Studies Atas Matinya Makna. Yogyakarta: Jalasutra.
Piliang, Y. A. (2010). Post Realitas: Realitas Kebudayaan dalam Era PostMetafisika. Yogyakarta: Jalasutra.

Ridwan, N. K. (2004). Agama Borjuis: Kritik Atas Nalar Islam Murni. Yogyakarta: Ar Ruzz.

Rivers, W. L., J. W. Jensen, dan Peterson, T. (2003). Media Massa dan Masyarakat Modern (cet. II). Jakarta: Kencana.

Shrum, L. J. (ed), (2010). Psikologi Media Entertainment: Membedah Keampuhan Periklanan Subliminal dan Bujukan yang tak Disadari Konsumen (terj. An Ismanto). Jalasutra: Yogyakarta.

Storey, J. (2007). Cultural Studies dan Kajian Budaya Pop: Pengantar Komprehensif Teori dan Metode (terj. Laily Rahmawati). Yogyakarta: Jalasutra.

Strinati, D. (2004), Popular Culture: Pengantar Menuju Teori Budaya Populer (terj. Abdul Mukhid). Yogyakarta: Bentang.

Taylor, P. A. and J. L. L. Harris (2008). Critical Theories of Mass Media: Now and Then. England: Open University Press

Turner, B. S. (1983). Religion and Social Theory: A Materialist Perspective. London: Heinemann Educational Books.

Verene, D. P. (1979). Symbols, Myth, and Culture: Essays and Lectures of Ernst Cassirer. U.S.A: Yale $U P$. http://www.fiu.edu/ morriss. 